dorsal, subdorsal (below the white one) and subventral bands appear.

Stage II. Head with conical pointed lobes; four conical points on the cervical shield, the posterior pair small, anal flap triangular and with the anal feet large. Dark brown, paler subrentrally, on the anal plate and feet; densely white frosted with numerous granules which segregate to form a linear pale subdorsal line. Width of hend about $+\mathrm{mm}$. The larra is a slender normal Geometrid.

Stage III. Lobes of head conical, high and pointed, the vertex therefore deeply notched; width $6 \mathrm{~mm}$. A pair of similar conical points on the cervical shield anteriorly. Anal plate pointed behind. Other. wise the larva is smooth, slender, ot a pale dead-leaf brown, frosted with whitish granules that form narrow, obscure, subdorsal, lateral and subventral lines and oblique ones between the subdorsal and lateral. Setice obsolete except on joint $1_{3}$.

Stage II. Ilead high with pointed flat lobes, greenish brown, brown on the angles and narrowly in two lines that form an $\mathrm{X}$. mark with the clypeal sutures; width $.5 \mathrm{~mm}$.
The points on the cervical shield are not so high as the lobes and are roughened; anal plate with a pointed projection; anal footplate large. Body slender, smooth, greenish brown, thickly white granular, forming faintly raised pale lines one granule wide; a dorsal, subdorsal, way lateral (almost forming a series of obliques) and subventral, all obscure. A series of dorsal, interseg. mental, deep brown dashes on joints 5 to 9 .

Stage I: llead roughly granular, I. 5 $\mathrm{mm}$. wide, marked as hefore. but there is a whitish slade on the front of each lobe. Cervical horns red tipped. Otherwise as before. Towards the end of the stage the larvate hecane shrunken so that the dorsal brown spots were occluded in the incisures; they looked shorter and thicker and more densely granular. They sit erect without spinning a supporting thread.

The species is single brooded. Eggs laid June 1 th from moths that were at the end of their time of flight. The larvae spun August fth and pupated on the 7 th, passing the winter in this state. The larvae fed on the red onk (2uercus coccinea). Found at Brookhaven, Long Island, N. Y.

\title{
DESCRIPTION OF THE TYPE OF POLYDONTOSCELIS ASHM.
}

\section{BY WILlian H. ASHMEAD, WASHINGTON, D. C.}

In my generic tables of some Homoptera, published in Entomologia Americana, vol. V, p. 126, I characterized a new genus under the name of Polydontoscelis, the type of which has never been described. This I propose to do now since the type is requested of ne for study.

Polydontoscelis differs from Aethalion Latreille, principally by having no cross-veins on the clavus, the cross-veins in the costal cell being more numerous, the submedian cell having only one cross-vein, while all the tibiae have a broad rather deep, longitudinal channel outwardly, the hind and lower edge of the posterior tibiae being armed with numerous minute teeth.

Polydontoscelis cintifrons n. sp.Length to tip of tegmina $9.5 \mathrm{~mm}$; breadth across shoulders $3.6 \mathrm{~mm}$. Brownish-yellow with a greenish tinge, and probably greenishyellow in life. Head seen from in front with two transverse bands; pleura with a longitudinal black band, extending forward and connected with a similar band on the 
cheeks. Thorax above punctate, with a median carina which is connected anteriorly with much abbreviated lateral carinae that converge toward the tegulae but which do not quite attain to the middle of the mesonotum; on each side of the middle carina is a blackish or dusky streak; the depressions on the onter side of the lateral carinae are also blackish, while there is also an oblique, dusky band just beyond and interstitial with them; scutellum with a trianguiar black spot at base: most of the cross-veins in the tegmina are black or piceous-black, while the longitudinal veins are interrupted with black marks. Legs and especially the femora sprinkled with black dots; anterior tibiae with the apical two-thirds of the channel and a spot near base, base of second tarsal joint and the last tarsal joint above black; middle tibiae with a spot in channel at base, another at apex and at middle beneath black; hind tibiae with a narrow annulus at base, another at the middle and the apex black. Abdomen immaculate; terminal ventral segment much longer than wide, at apex truncate; genital valves triangular, the plates lanceolate curving upwards.

Hab. - St. Nicholas, Florida.

Described from a single specimen taken on gall-berry bushes (Ilex glabra), by sweeping.

\section{PROCEEDINGS OF THE CLUB.}

Ifth April, IS99. The zoSth meeting was held at 156 Brattle Street, Mr. J. W. Folsom in the chair.

The annual report of the treasurer was read and accepted.

Mr. S. H. Scudder read an article by Mr.
A. H. Kirkland on the abundance of Cryttorlynchus lafathi along portions of the senconst of Massachunetts, and the injuries caused by this weevil, especially to the bahm of Gilead poplar.

Mr. J. W. Folsom said that he had found it quite abundant in Cambridge, where it has often caused much damage to willows.

Mr. C. C. Adams showed specimens of the larva of Oestrus ovis taken from the skull of a sheep.

Mr. W. L. WV. Field stated that he had recently been studying historically the cases of the occurrence of southern butterflies in New England, which he believed were due less to the fact that the species were actually extending their range of distribution northward than to the increase of collectors; this would account for the fact that such instances are more frequently noted in recent years.

He also spoke of the abundance in late years in sonthern New Ilampshire of Clisiocampa disstria, a species injurious to the strgar maple; and said that he had found living caterpillars of Pieris rafac in cabbages in January, some of which had apparently been feeding recently.

Mr. S. H. Scudder exhibited Charpentier's figure of Eurycuema herculanea, a Phasmid recently found to be parthenogenetic, ron Brunn stating that a German merchant in Batavia had reared three successive generations from isolated females, all the progeny also being female, with the possible exception of a single malformed individual which died young.

Mr. J. W. Foisom showed specimens of Periflaneta americana received at Trenton, N. J., in bales of cocon fibre from Manila.

\section{A. SMITH \& SONS, 269 PEARL STREET, New York.}

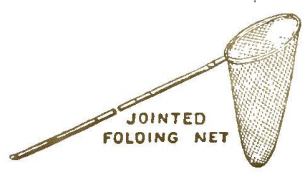

MANTFACTERERS AND IMPORTFRS OF GOODS FOR EHTOMOLOGISTS, Klaeger and Carlsbad Insect Pins, Setting Boards, Folding Nets, Locality and Special Labels, Forceps, Sheet Cork, Etc. Other a rticles are being added, Send for List. 

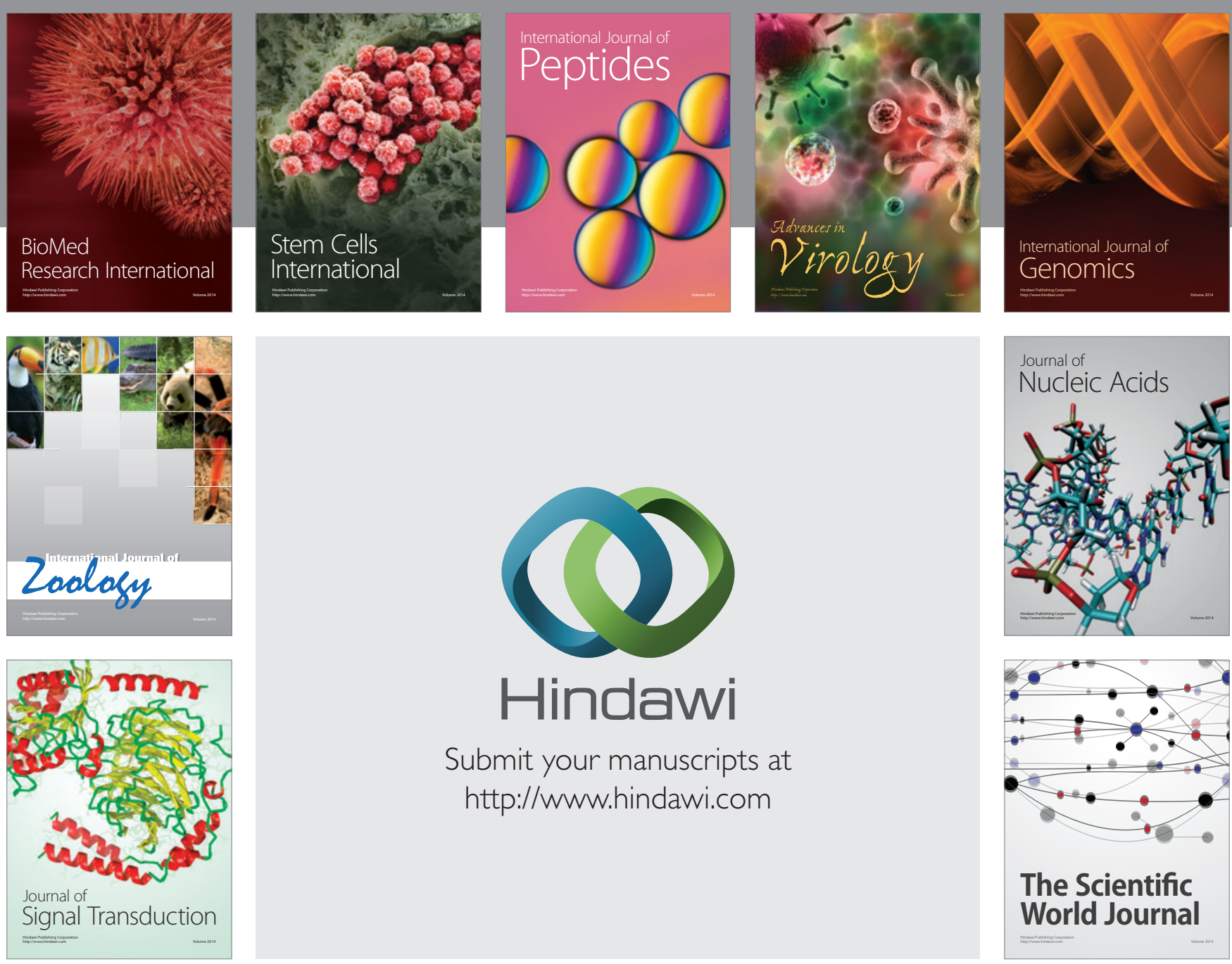

Submit your manuscripts at

http://www.hindawi.com
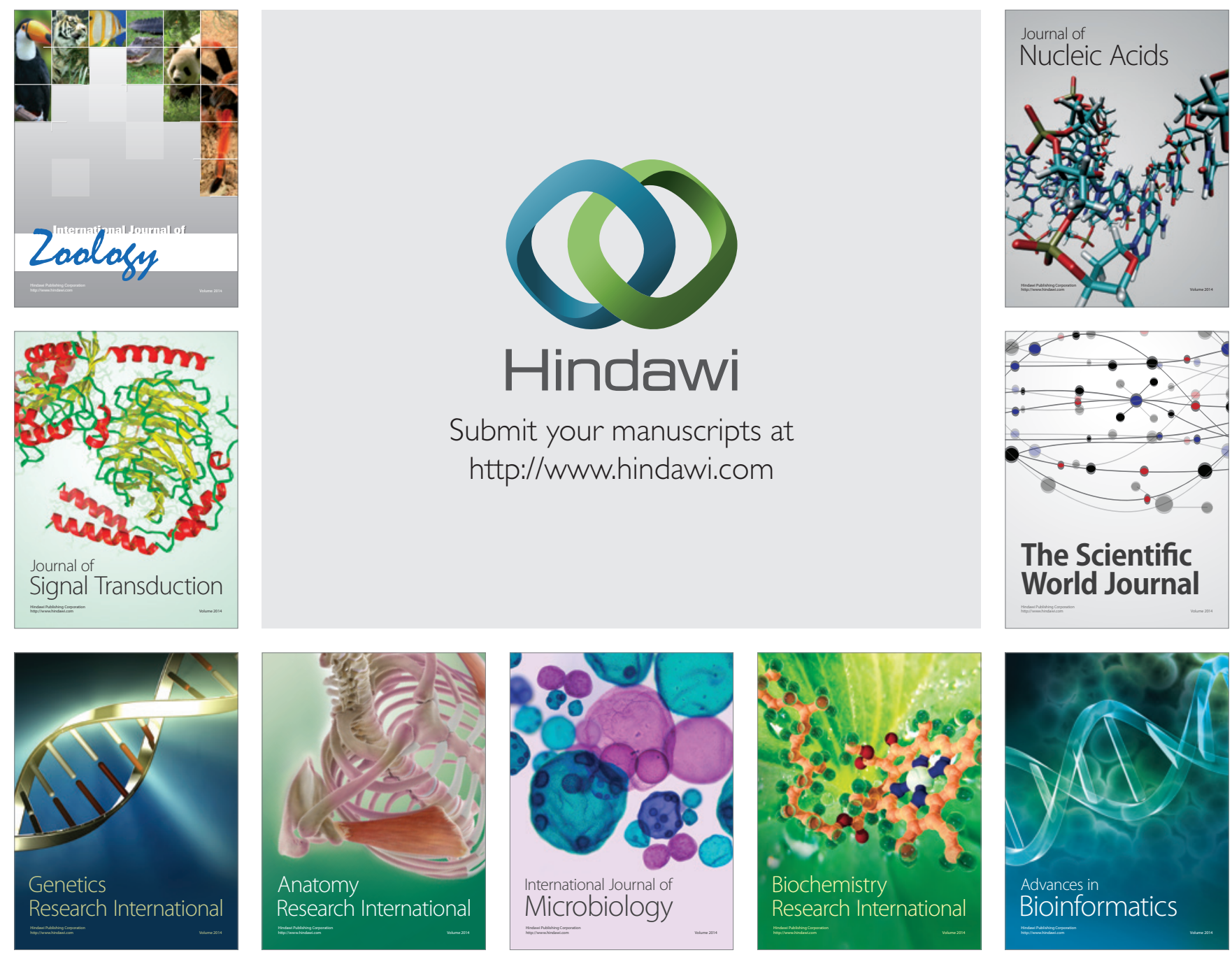

The Scientific World Journal
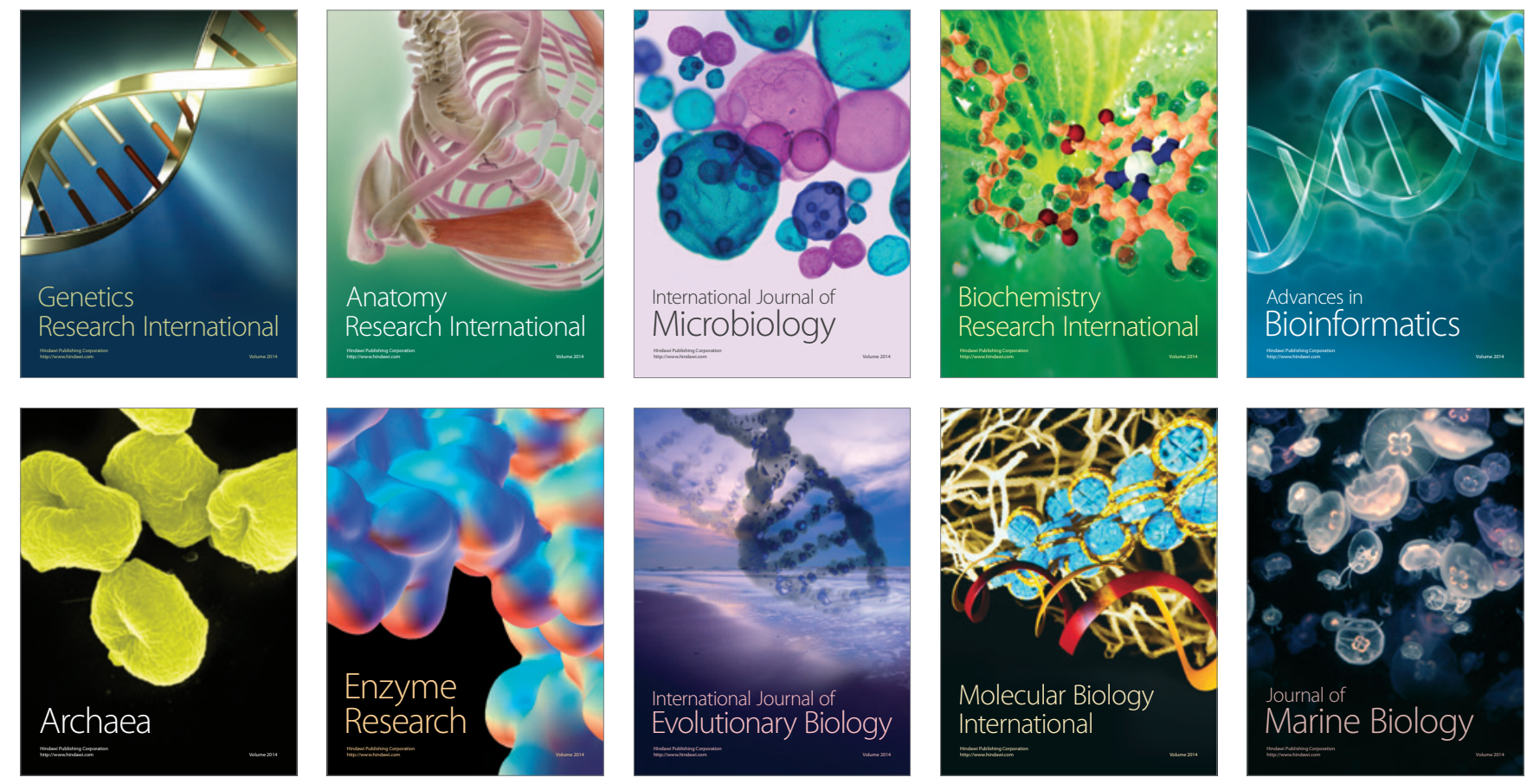